\title{
THE REMOVAL OF LEAD (II) IONS FROM AQUEOUS SOLUTIONS BY ACID-ACTIVATED CLAY MODIFIED WITH SODIUM CARBOXYMETHYL CELLULOSE
}

\author{
VOJKAN, M. M. ${ }^{1 *}$ - MILAN, J. ${ }^{1}$ - SNEŽANA,.$^{2}{ }^{2}$ - MAJA, S. $^{2}-$ STANIŠA, S. $^{3}-$ MAJA, V. ${ }^{1}$ \\ - BOJANIĆ, N. ${ }^{4}$ \\ ${ }^{1}$ Department of Pharmacy, Faculty of Medicine, University of Niš \\ Bulevar dr Zorana Đinđića 81, Niš, Serbia \\ (phone: +381-18-422-6644) \\ ${ }^{2}$ Department of Chemistry, Faculty of Science and Mathematics, University of Niš \\ Višegradska 33, Niš, Serbia \\ (phone: +381-18-223-430) \\ ${ }^{3}$ Faculty of Technology, University of Niš \\ Bulevar Oslobođenja 124, Leskovac, Serbia \\ (phone: +381-16-247-203) \\ ${ }^{4}$ Faculty of Medicine, University of Niš \\ Bulevar dr Zorana Đinđića 81, Niš, Serbia \\ (phone: +381-18-422-6644) \\ *Corresponding author \\ e-mail: vojkanmm_serbia@yahoo.com; phone: +381-64-308-0893 \\ (Received $15^{\text {th }}$ Jun 2017; accepted $20^{\text {th }}$ Sep 2017)
}

\begin{abstract}
The suitability of clay modified with sodium carboxymethyl cellulose was tested for the removal of $\mathrm{Pb}^{2+}$ from aqueous solutions. The effect of $\mathrm{pH}$ on the adsorption process was investigated in the $\mathrm{pH}$ range from 1 to 9 . Tests were conducted at different temperatures: $20^{\circ} \mathrm{C}, 30^{\circ} \mathrm{C}, 40{ }^{\circ} \mathrm{C}, 50^{\circ} \mathrm{C}$ and $60{ }^{\circ} \mathrm{C}$. The effect of initial concentration of adsorbate on lead removal was analysed using solutions with lead concentrations from 50-150 mg L ${ }^{-1}$. Also, the amount of adsorbent in the process of removing lead was determinated. The efficiency of lead removal was observed to be $86.19 \%$ from solution with the initial concentration $100 \mathrm{mg} \mathrm{L}^{-1}$. Obtained Freundlich adsorption isotherms show extremely high correlation coefficient $\mathrm{R}^{2}$, i.e. processes of equilibria on the investigated clays can be described using this equation. The series of conducted experiments shows that the clay modified with carboxymethyl cellulose is suitable for the removal of lead from waste waters. Further researches should be focused on modifying clay with other long chain molecules which can improve adsorption properties.
\end{abstract}

Keywords: adsorption, ICP-OES, scanning electron microscopy, FTIR spectral analysis, waste waters

\section{Introduction and literature review}

Heavy metals are very toxic and that their discharges from industrial plants into waste waters cause harmful effects on human health and the environment is well known. Due to the lead production and its widespread use, it can contaminate air, soil, and via them enter the food chain through food of plant and animal origin. Main sources of lead in the environment are petrol to whom tetraethyl lead is added as a detonator (in many countries lead is fallen into disuse with this purpose (WHO, 2011) metal industry, industrial waste, paint colours, lead water pipes in old buildings etc) (Mirić and Šrbajić, 2002). According to the data of World Health Organization (2011), concentration of lead in water should be below $10 \mu \mathrm{g} \mathrm{L}^{-1}$. 
Lead is one of the oldest known toxicants. Around $10 \%$ of lead is getting absorbed from digestive tract. According to IARC (International Agency for Research on Cancer), lead is belonging to group 2 of the potential human carcinogen agent (Mirić and Šorbajić, 2002). Exposure to lead during pregnancy affects the DNA methylation status of the fetal germ cells, which leads to altered DNA methylation in grandchildren's neonatal dried blood spots (Sen et al., 2015). Long exposure to low doses mainly harms nervous system (these changes occur at concentrations in blood from 100-150 $\mu \mathrm{g} \mathrm{L}^{-1}$ ). Mechanism of its toxicity on nervous system can be one of the following: direct neurotoxicity (apoptosis excitotoxicity, influences on neurotransmitter storage and release process), calcium replacement (lead has ability of passing through blood-brain barrier; back-transport of lead via the Ca-ATPase pump) (Lidsky and Schneider, 2003). Toxic effects of lead are manifested as renal failure, hypertension, fertility problems and spontaneous miscarriage, and even fatal outcome due to problems with cardiovascular system (WHO, 2011). Toxic effects are consequences of the inactivation of particular enzyme systems, binding to $\mathrm{SH}$ groups of proteins, replacements of essential elements (Mirić and Šorbajić, 2002). Some techniques for removing lead from water are: removing by coffee grounds as vegetable biomass (Tokimoto et al., 2004); adsorption onto calcined phosphate (Aklil et al., 2004); adsorption onto zeolites (Scott et al., 2002; Panayotova and Velikov, 2002), adsorption onto clays (Celis et al., 2000; Cooper et al., 2002). Addition of polymers on the physico-chemical properties of bentonite was tested for cleaning water solutions (Stojiljkovic et al., 2014). All mentioned techniques are relatively cheap. Therefore, it is an imperative to find suitable and cheap technique for the removal of toxic metal from the environment.

Generally, techniques developed for the removal of toxic metals from water solutions include precipitation, ion exchange, adsorption, filtration, electrodeposition, reversed osmosis (Rao et al., 2010). Clay is finely granulated soil, which includes combination of one or more clay minerals and metal oxides or organic substances contained in trace amounts (Guggenheim and Martin, 1995). Adsorption of heavy metals was investigated in several works using the clay as the adsorbent: lead on the bentonite (Zhu et al., 2008), lead on the clay activated with acid (Resmi et al., 2012), chromium on the modified clay (Arfaouia et al., 2008), and Inglezakisa et al. (2007) achieved the efficiency of $100 \%$ in the removal of $\mathrm{Pb}^{2+}$ from water solutions using clinoptilolite and bentonite as adsorbents. The influence of different factors affecting the adsorption was investigated, such as $\mathrm{pH}$, agitation time, temperature, quantity of adsorbents, concentration of adsorbate, kinetics of adsorption (Resmi et al., 2012). Maximal adsorption capacity of natural clays for $\mathrm{Pb}^{2+}$ ion is $104.28 \mathrm{mg} \mathrm{g}^{-1}$ (Zhu et al., 2008). The efficiency of the removal of lead ions using acid activated clay is equal to $92.4 \%$ at the initial concentration $100 \mathrm{mg} \mathrm{L}^{-1}$ at $\mathrm{pH}=6$ and $30{ }^{\circ} \mathrm{C}$ (Resmi et al., 2012). Bentonite is used in food industry as an anticaking agent, helping prevent food particles from sticking together (E 558). There are no data in the literature that anyone performed the removal of lead from aqueous solutions using the bentonite modified with sodium carboxymethyl cellulose (NaCMC), a food additive labeled as E 466 (Mirić and Šorbajić, 2002).

In this paper it was investigated the efficacy of the clay modified with $\mathrm{NaCMC}$ for the removal of lead from aqueous solution by adsorption and monitoring of the influence of $\mathrm{pH}$ value, temperature, dose of the adsorbent and the concentration of adsorbate was performed. The aim of this work was to create a new adsorption material, 
clay modified with long chain molecule (in this case carboxymethil cellulose), with improved properties for heavy metal ions adsorption (Zhu et al., 2008). New adsorption material provides simple and cheap technique for removing $\mathrm{Pb}$ (II) ions from waste waters.

\section{Material and methods}

\section{Reagents}

NaCMC was purchased from Weifang Lude Chemical Co., Shandong China. For the acid activation of clay (bentonite-Riznica prirode, Serbia) concentrated $\mathrm{HCl}$ (p.a. Zorka Pharma, Serbia) was used. Lead nitrate (p.a. Alkaloid Skopje) was used for the preparation of adsorbate solution. Multistandard-UltraScientific Analytical Solutions (USA) were used for the quantitative determination of lead. Deionized water was used for the preparation of all solutions.

\section{Apparatus}

The following apparatus were used: ICP-OES iCAP 6000 (Thermo Scientific, United Kingdom), FTIR spectrometer Bomem MB-100 (Hartmann \& Brown, Canada) with standard DTGS/KBr detector, scanning electronic microscope JSM-5300 (JEOL, Japan), the device for the preparation of samples for electron microscopy JFC-1100E ION SPUTTER (Jeol Co., Japan), digital pH meter (HANNA, USA), and hothouse (Trade Raura, Spain).

\section{Adsorbent}

Acid activated clay was prepared by the treatment of crude clay with concentrated $\mathrm{HCl}$. $15 \mathrm{~g}$ bentonite clay was suspended in the beaker with $300 \mathrm{~mL}$ deionized water. Afterwards NACMC was added in the quantity of $1 \%$ of clay mass $(0.15 \mathrm{~g}$ ) (modified clay GI), $3 \%$ (GII) and $5 \%$ (GIII) and then heated at $90{ }^{\circ} \mathrm{C}$ and mixed on rotary mixer (1-2 h). $5 \mathrm{~mL}$ of conc $\mathrm{HCl}$ was added dropwise. The probe was left overnight, and then filtered through Buchner funnel on vacuum pump and rinsed with plenty of deionized water until negative reaction on chlorides. Modified clay was dried in the oven at $110^{\circ} \mathrm{C}$ to constant weight, left overnight and then smashed in the mortar. Before the addition of $\mathrm{NaCMC} \mathrm{pH}$ was $9.2 \pm 0.1$, while $\mathrm{pH}$ after the addition of $\mathrm{NaCMC}$ and $\mathrm{HCl}$ was $1.35 \pm 0.1$.

\section{FTIR spectral analysis}

Samples of carboxymethyl cellulose, modified clays (GI, GII, GIII) and unmodified clay (G0) were recorded on FTIR spectrometer. Scanning was performed in the range of wavelengths from $4000-400 \mathrm{~cm}^{-1}$ with the resolution $4 \mathrm{~cm}^{-1}$.

\section{SEM analysis}

SEM analysis of surface samples was performed by scanning electron microscope JEOL JSM-5300, which is operated at a working potential of $30 \mathrm{kV}$, and the depth of penetration of electron beam was $10 \mathrm{pm}$. Characteristics of surface samples are observed at different magnifications $(1000 \times, 2000 \times, 5000 \times)$. SEM-EDS analysis was performed using the same scanning microscope, but with the detector (probe) Linx Analytical QX 2000b. 


\section{Adsorbate}

The stock solution of $\mathrm{Pb}^{2+}$ ions $\left(1000 \mathrm{mg} \mathrm{L}^{-1}\right)$ were prepared by weighing exactly known mass of $\mathrm{Pb}\left(\mathrm{NO}_{3}\right)_{2}$ and dissolving in deionized water in volumetric flask. Thus solution was used for further investigations by diluting to required concentrations.

\section{Adsorption study}

Particular mass of adsorbent was added into the beaker with $50 \mathrm{~mL}$ of lead nitrate solution of particular concentration. Solutions were mixed for $20 \mathrm{~min}$ on the rotary mixer (speed $150 \mathrm{rpm}$ ) at particular temperature, and filtered through filter paper (Whatman Grade 589). Concentration of the lead in the filtrate was determined using optical emission spectrometry with inductively coupled plasma (ICP-OES) (Yi et al., 2011). The influence of the temperature was investigated by heating on the water bath, and the influence of $\mathrm{pH}$ by the addition of $\mathrm{HCl}$ and $\mathrm{NaOH}$ solutions to solution of $\mathrm{Pb}^{2+}$ ions (Adhikari and Singh, 2003).

Adsorption capacity can be calculated according to the equation (Eq. 1):

$$
q_{e}=\left(C_{o}-C\right) \frac{V}{m}
$$

where $c_{0}$ is the initial concentration of $\mathrm{Pb}^{2+}$ ions, $c$ remaining concentration of $\mathrm{Pb}^{2+}$ in the state of equilibrium, $V$ volume of the solution and $m$ mass of the adsorbent (Yasemin and Zeki, 2007).

\section{Results and discussion}

\section{Characterization of adsorbents}

Scanning electron microscopy

According to the producer specification, bentonite clay contains minerals: montmorillonite, kaolinite, illite and hydromuscovite. Chemical composition of the initial sample is presented in Table 1 .

Table 1. Chemical composition of the initial bentonite sample

\begin{tabular}{c|c|c|c|c|c|c|c}
\hline \multicolumn{1}{c}{ Bentonite } \\
\hline $\begin{array}{c}\text { Chemical } \\
\text { composition }\end{array}$ & $\mathrm{SiO}_{2}$ & $\mathrm{Al}_{2} \mathrm{O}_{3}$ & $\mathrm{~K}_{2} \mathrm{O}$ & $\mathrm{Fe}_{2} \mathrm{O}_{3}$ & $\mathrm{TiO}_{2}$ & $\mathrm{MgO}$ & $\mathrm{CaO}$ \\
Content, \% & 67.81 & 24.73 & 3.25 & 1.89 & 1.06 & 0.93 & 0.33 \\
\hline
\end{tabular}
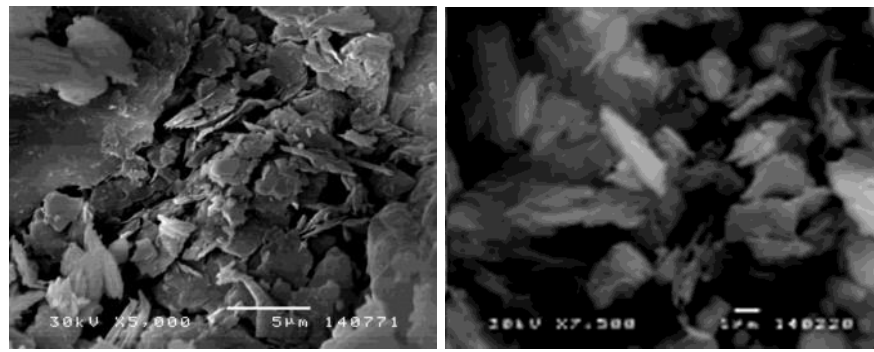

Figure 1. SEM of unmodified clay 

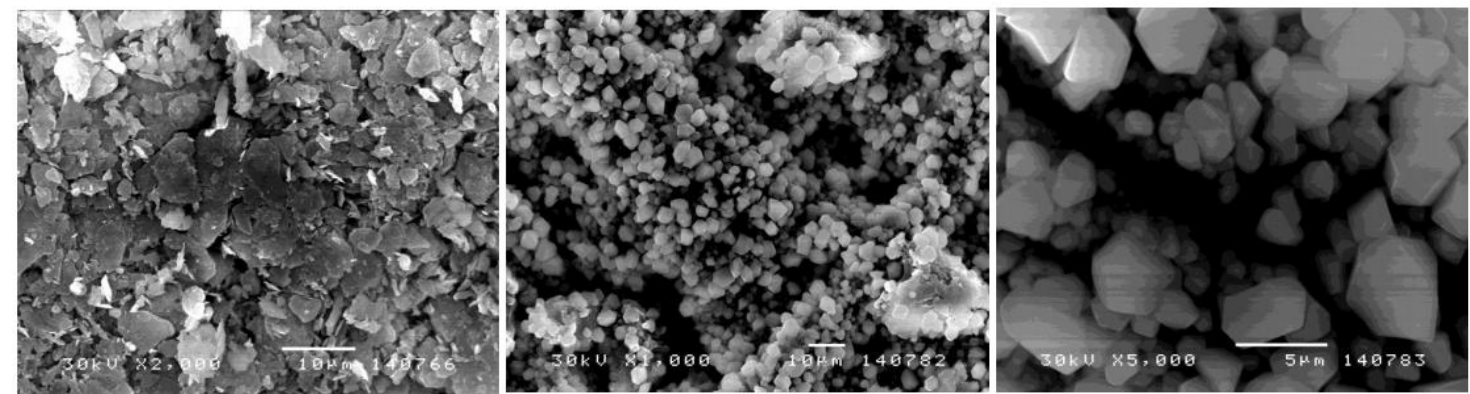

Figure 2. SEM of clay modified with sodium carboxymethyl cellulose

SEM analysis of unmodified clay (5000× magnification) shows characteristic morphology of clay minerals, i.e. platelet particles of different sizes (Fig. 1). SEM analysis of GI sample indicates lamellar particles with dominant fraction of 5-10 $\mu \mathrm{m}$ in diameter. Microphotographs of GII sample show polyhedral crystals, which are more evident on SEM analysis of GIII sample. Having on mind that there are no published publications of clay modification with $\mathrm{NaCMC}$, we assumed these crystals originated from $\mathrm{NaCl}$ were formed in the reactions of $\mathrm{HCl}$ and sodium from $\mathrm{NaCMC}$ (Fig. 2).

SEM-EDS analysis shows that predominant elements in unmodified clay are: $\mathrm{Fe}, \mathrm{Al}$, $\mathrm{Si}$, and O. In sample of GI, GII and GIII aluminum is the most dominant, due to leaching of Fe during the synthesis of composite material.

\section{FTIR spectral analysis}

FTIR spectra of modified clays (GI, GII, GIII) (Fig. 3) show OH band at $3430.65 \mathrm{~cm}^{-1}$, $3433.42 \mathrm{~cm}^{-1}, 3433.87 \mathrm{~cm}^{-1}$ succesively characteristic for clay minerals (montmorillonite, illite, hydromuscovite and kaolinite).

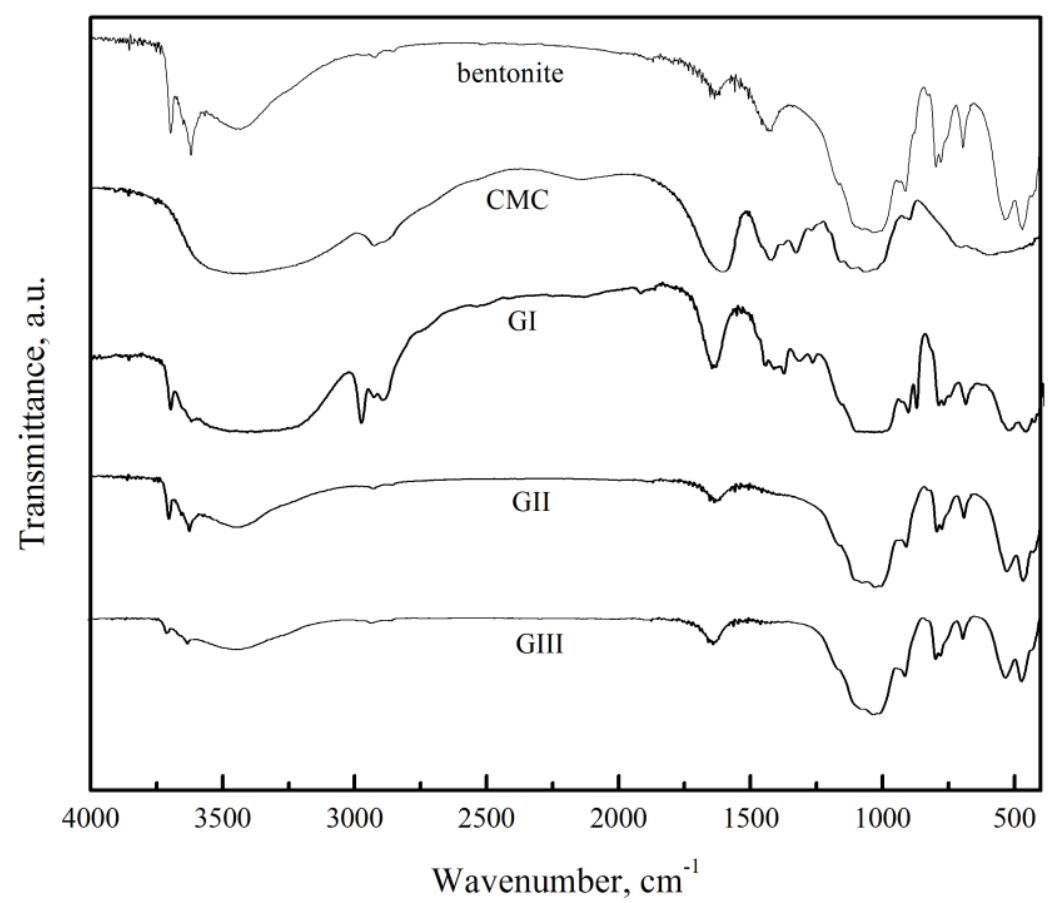

Figure 3. FTIR spectra of bentonite, CMC and adsorbents GI, GII and GIII 
Also, in spectra (G0, GI, GII, GIII) it is clearly visible the intensive band coming from deformational vibration of Si-O bond, with maximums at $1033.27 \mathrm{~cm}^{-1}, 1028.52 \mathrm{~cm}^{-1}$, $1037.13 \mathrm{~cm}^{-1}$ and $1019.46 \mathrm{~cm}^{-1}$ (characteristic for alumosilicates present in the clay). At the spectrum of modified clay GI, peaks at 2926.41 and $2854.77 \mathrm{~cm}^{-1}$ come from C-H vibrations and they are results of the presence of carboxymethyl cellulose. In spectra of GII and GIII, these bands are less pronounced, which means that sample GI contains mostly unmodified carboxymethyl cellulose, although in the process of the preparation the least quantity of this organic compound as a modifier of the surface and adsorption characteristics of clay was used.

\section{Adsorption experiments}

\section{Influence of $\mathrm{pH}$ on the adsorption}

Lead adsorption $\left(50 \mathrm{~mL}\right.$ of the $\mathrm{Pb}^{2+}$ solution, concentration $100 \mathrm{mg} \mathrm{L}^{-1}$ ) on modified clay $(1.00 \mathrm{~g})$ was investigated at $\mathrm{pH}$ values $1,3,5,7$ and 9. At Figure 4, it was given the dependence onadsorption capacity of adsorbent for $\mathrm{Pb}^{2+}$ ions $\left(\mathrm{mg} \mathrm{g}^{-1}\right)$ as a function of $\mathrm{pH}$ of the environment. It is obvious that the adsorption increases with the increase of $\mathrm{pH}$ value. In strong acidic environment, the number of $\mathrm{H}_{3} \mathrm{O}^{+}$ions is higher that the number of $\mathrm{Pb}^{2+}$ ions in the solution, so at low $\mathrm{pH}$ values the active places for the adsorption are occupied with $\mathrm{H}_{3} \mathrm{O}^{+}$ions which unable the adsorption of $\mathrm{Pb}^{2+}$ ions (Bhattacharyya and Gupta, 2007). Qiu et al. (2008) noticed the existence of lead in different forms at different $\mathrm{pH}$, such as $\mathrm{Pb}^{2+}, \mathrm{Pb}(\mathrm{OH})^{+}, \mathrm{Pb}(\mathrm{OH})_{2}, \mathrm{~Pb}(\mathrm{OH})^{3-}, \mathrm{Pb}(\mathrm{OH})_{4}{ }^{2-}$, etc. At $\mathrm{pH}=6.7$, the precipitation of lead in the form of hardly soluble $\mathrm{Pb}(\mathrm{OH})_{2}$ occurred, so the decrease of the concentration in this $\mathrm{pH}$ range can not be attributed to adsorption (Qiu et al., 2008). In any case, it is evident the increase of the percentage of removed lead by adsorption at $\mathrm{pH}$ values up to 7 . Similar results were obtained by Bhattacharya and Gupta (2007).

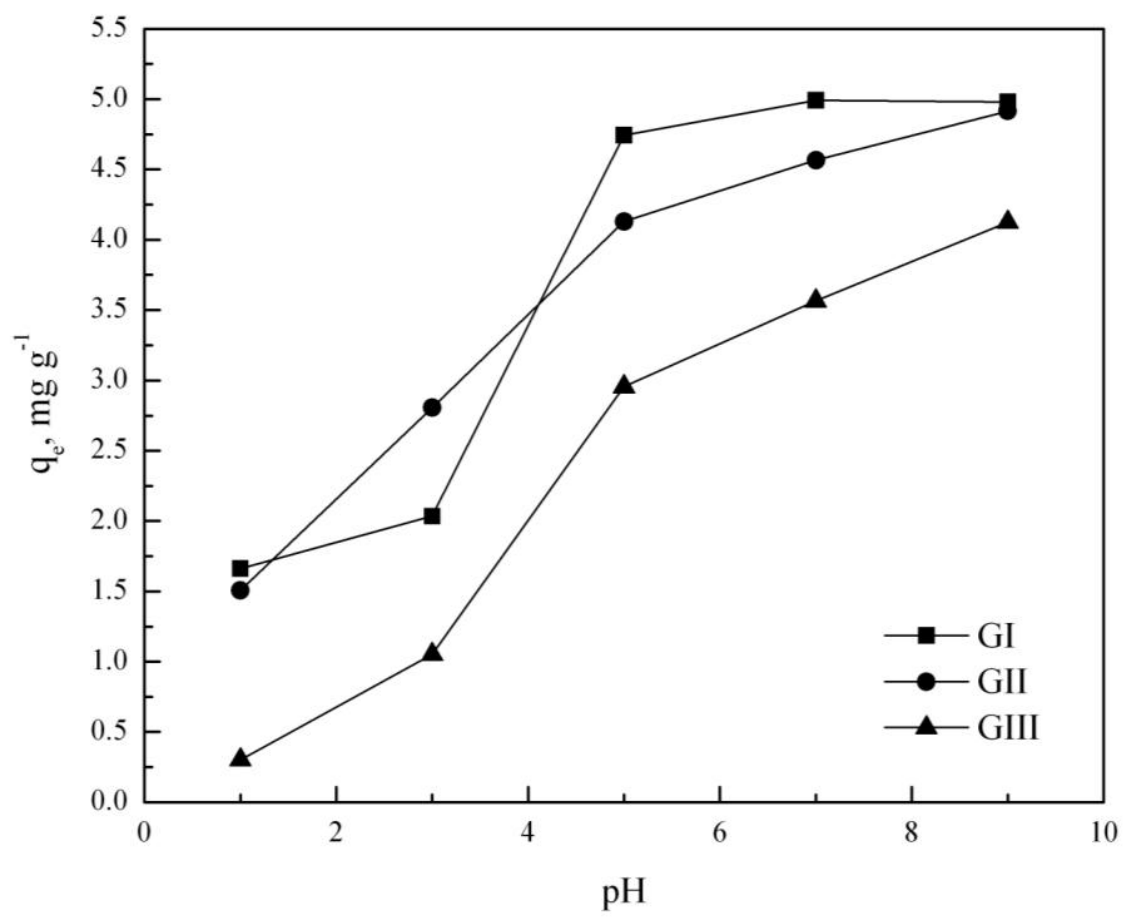

Figure 4. The influence of $\mathrm{pH}$ on the adsorption of $\mathrm{Pb}^{2+}$ ions 
Modified clay GI is the most sensitive to $\mathrm{pH}$ change which increases the possibility of its application.

\section{The influence of temperature on the adsorption}

The influence of the temperature on the adsorption of lead $\left(50 \mathrm{~mL}\right.$ of $\mathrm{Pb}^{2+}$ solution, $\left.\mathrm{c}=100 \mathrm{mg} \mathrm{L}^{-1}\right)$ on modified clay $(1.00 \mathrm{~g})$ was investigated at five different temperatures $\left(20{ }^{\circ} \mathrm{C}, 30{ }^{\circ} \mathrm{C}, 40{ }^{\circ} \mathrm{C}, 50{ }^{\circ} \mathrm{C}\right.$ and $\left.60{ }^{\circ} \mathrm{C}\right)$. From Figure 5, it is obvious that the increase of temperature causes the increase of $\mathrm{Pb}^{2+}$ adsorption from the solution, indicating that the adsorption of lead on the investigated adsorbents is an endothermic process. This increase is the most pronounced in case of sample GI.

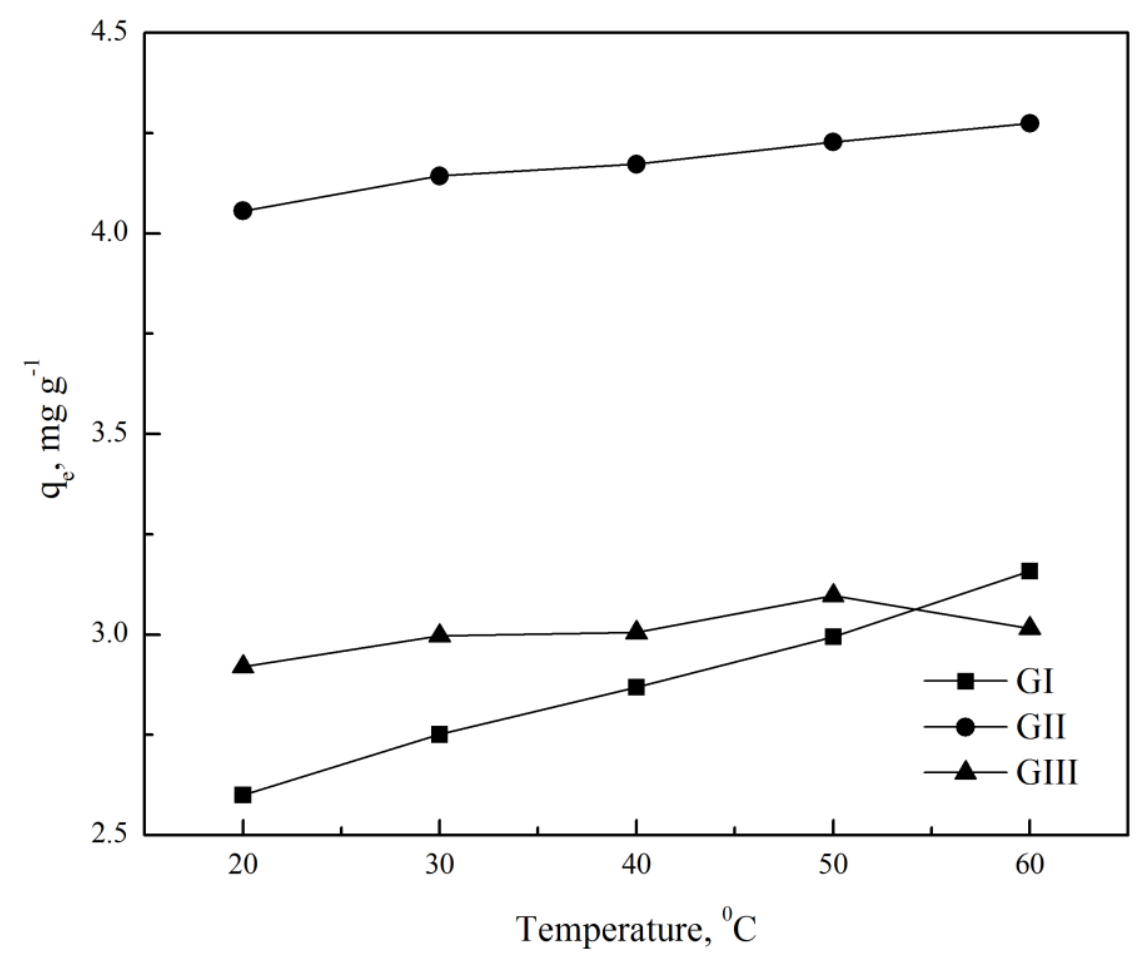

Figure 5. The influence of the temperature on the adsorption of $\mathrm{Pb}^{2+}$ ions

\section{The influence of the mass of the adsorbent}

The influence of the mass of the adsorbent on the adsorption of $\mathrm{Pb}^{2+}$ ions $(50 \mathrm{~mL}$ of $\mathrm{Pb}^{2+}$ solution, $\mathrm{c}=100 \mathrm{mg} \mathrm{L}^{-1}$ ) was investigated with the following weights of modified clay: $0.25,0.50,1.00,1.50$ and $2.00 \mathrm{~g}$. Results are shown in Figure 6 . It is obvious that increasing of mass of the adsorbent causes the increase of the percentage of adsorbed lead since the adsorption is carried out on the available surface, so for the solution of fixed concentration, the increase of the quantity of adsorbent gives the higher area i.e. more places for the adsorption (Chaari et al., 2008). 


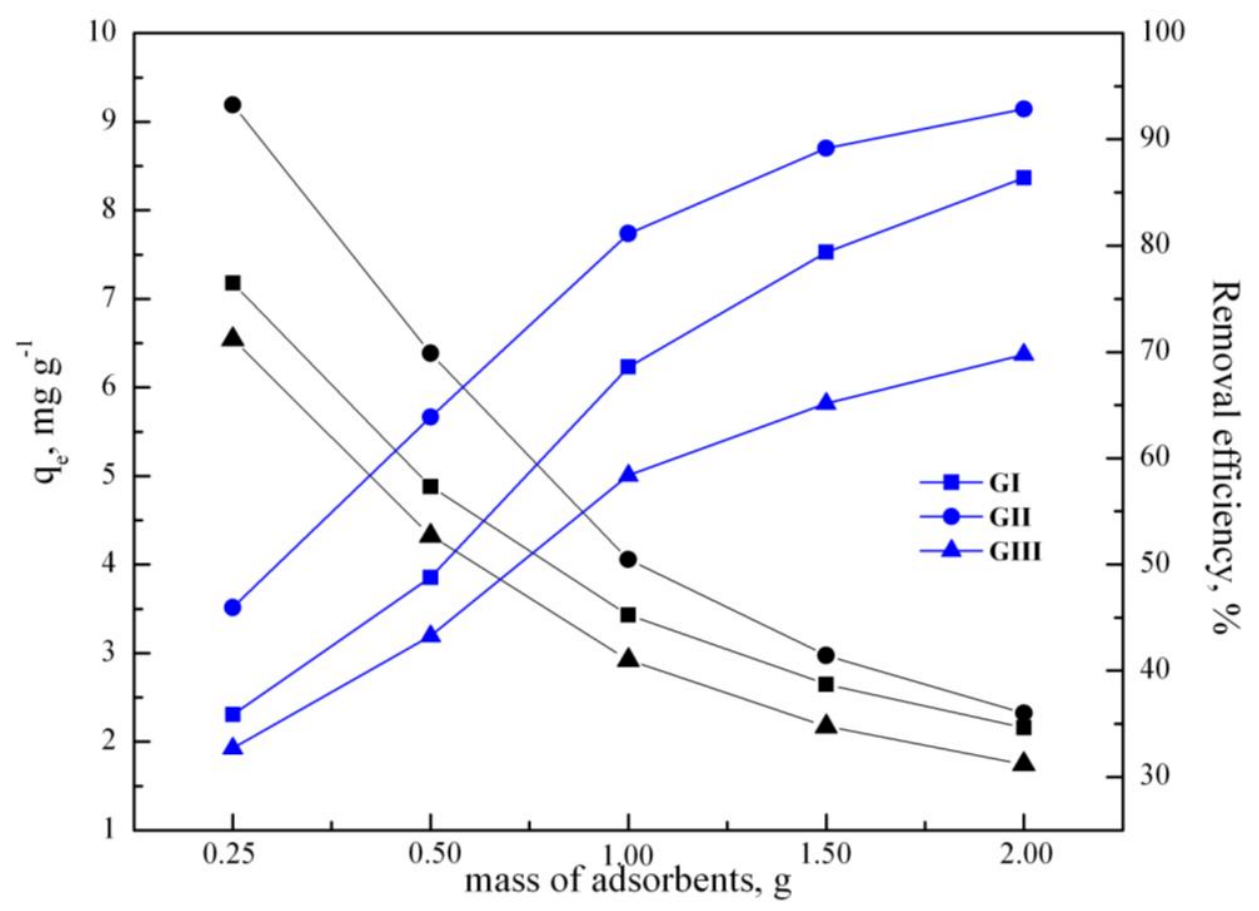

Figure 6. The influence of the mass of the clay on the adsorption of $\mathrm{Pb}^{2+}$ ions

The highest effect of the removal of $\mathrm{Pb}^{2+}$ ions was shown by the modified clay GII. $50 \mathrm{~mL}$ of the solution of different initial concentrations $\mathrm{Pb}^{2+}$ was added to $1 \mathrm{~g}$ of the modified clay. $\mathrm{pH}$ of solution was 5.0, and experiments were performed at $20{ }^{\circ} \mathrm{C}$ (Fig. 7).

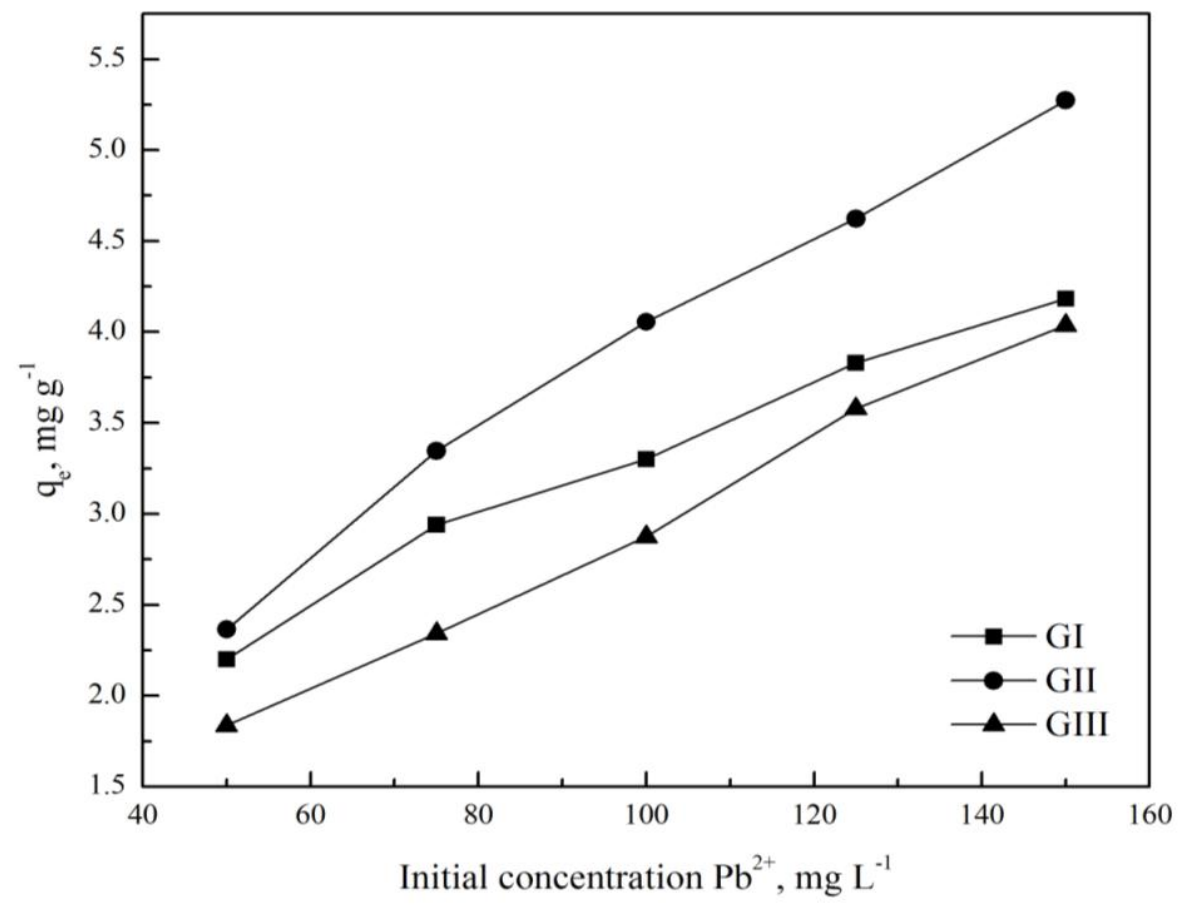

Figure 7. The influence of the initial concentration of adsorbate on the adsorption of $\mathrm{Pb}^{2+}$ ions 
Adsorption capacity of clay (adsorbate) GII is the highest and increases with increasing of initial concentration of $\mathrm{Pb}^{2+}$, while the smallest is for clay (adsorbate) GIII. The highest percentage of added NaCMC $(5 \%)$ is the reason of minimum adsorption capacity. The results show that under the same experimental conditions, adsorbate with $3 \%$ of $\mathrm{NaCMC}$ is the most efficient (with highest adsorption capacity). This can be explained by the formation of the most suitable structure with the addition of NaCMC in concentration of 3\%. The addition of polymer onto clay and improving the adsorption properties is also reported other authors (Stojiljkovic et al., 2014).

\section{Adsorption isotherms}

Based on the obtained results, Langmuir and Freundlich adsorption isotherms were applied for the investigation of modified clay.The Langmuir model assumes that the uptake of metal ions occurs on a homogeneous surface by monolayer adsorption without any interaction between adsorbed ions (Langmuir, 1918). The Langmuir parameters can be determined from a linearized form, by plotting Ce/qe vs. Ce (Fig. 8, Eq. 2):

$$
\frac{c_{e}}{q_{e}}=\frac{1}{K_{L q \max }}+\frac{1}{q_{\max }} c_{e}
$$

where $C_{e}$ is the equilibrium concentration of adsorbate $\left(\mathrm{mg} \mathrm{dm}^{-3}\right), \mathrm{q}_{\max }$ is the Langmuir equilibrium constant related to maximum monolayer coverage capacity $\left(\mathrm{mg} \mathrm{g}^{-1}\right)$, and $\mathrm{K}_{\mathrm{L}}$ is the Langmuir constant which is related to the enthalpy of adsorption $\left(\mathrm{dm}^{-3} \mathrm{mg}^{-1}\right)$.

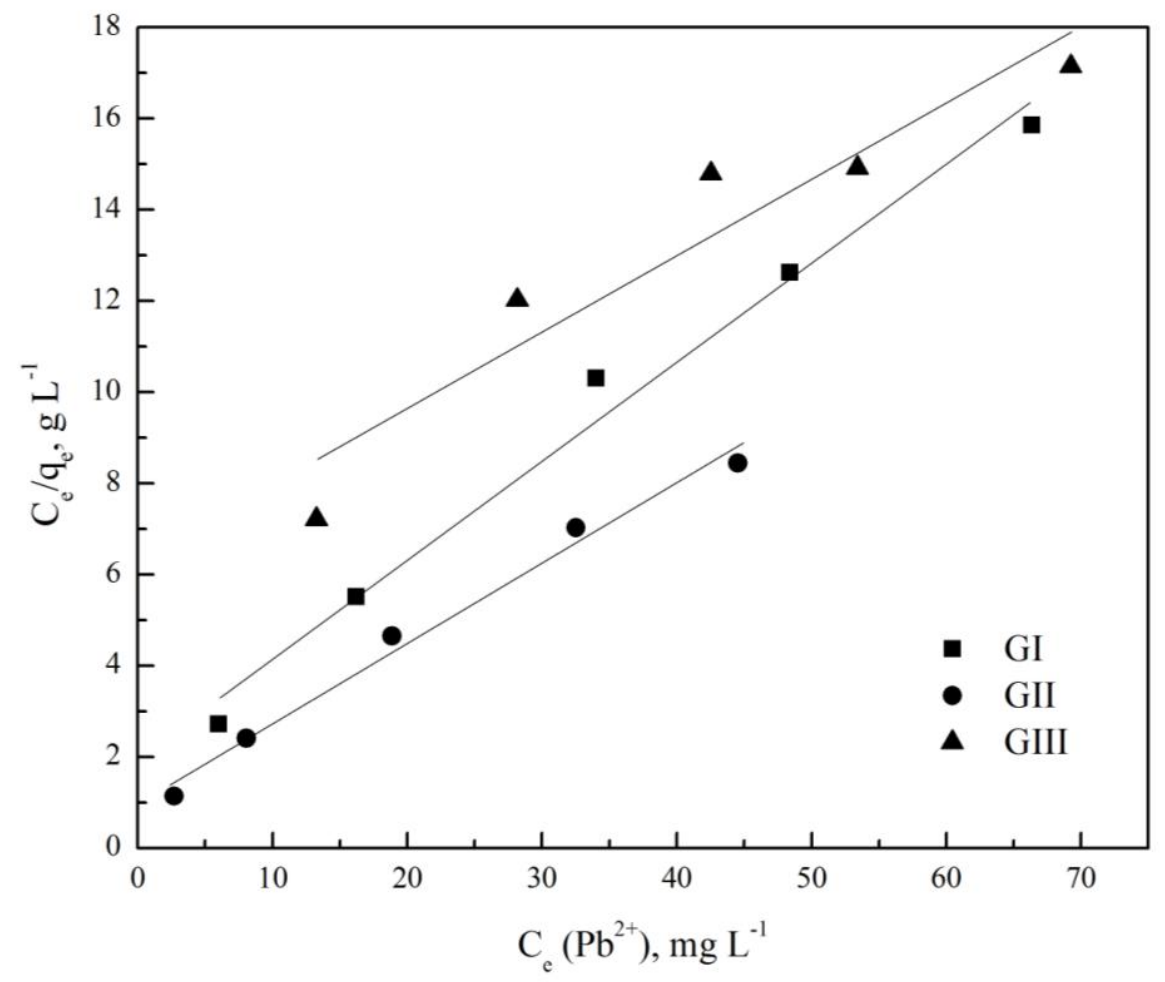

Figure 8. Langmuir adsorption isotherms for the adsorbents GI, GII and GIII 
Based on logarithmic form of Freundlich equation (Eq. 3):

$$
\log q_{e}=\log K_{f}+\frac{1}{n} \log c_{e}
$$

where $\mathrm{q}_{\mathrm{e}}$ is the adsorption capacity $(\mathrm{mg} / \mathrm{g}), \mathrm{K}_{\mathrm{f}}$ Freundlich constant, $1 / \mathrm{n}$ Freundlich exponent and $\mathrm{c}_{\mathrm{e}}$ concentration of $\mathrm{Pb}^{2+}$ ions in the equilibrium $\left(\mathrm{mg} \mathrm{dm}^{-3}\right)$, the plot of the $\log \mathrm{q}_{\mathrm{e}}$ against $\log \mathrm{c}_{\mathrm{e}}$ is presented (Fig. 9).

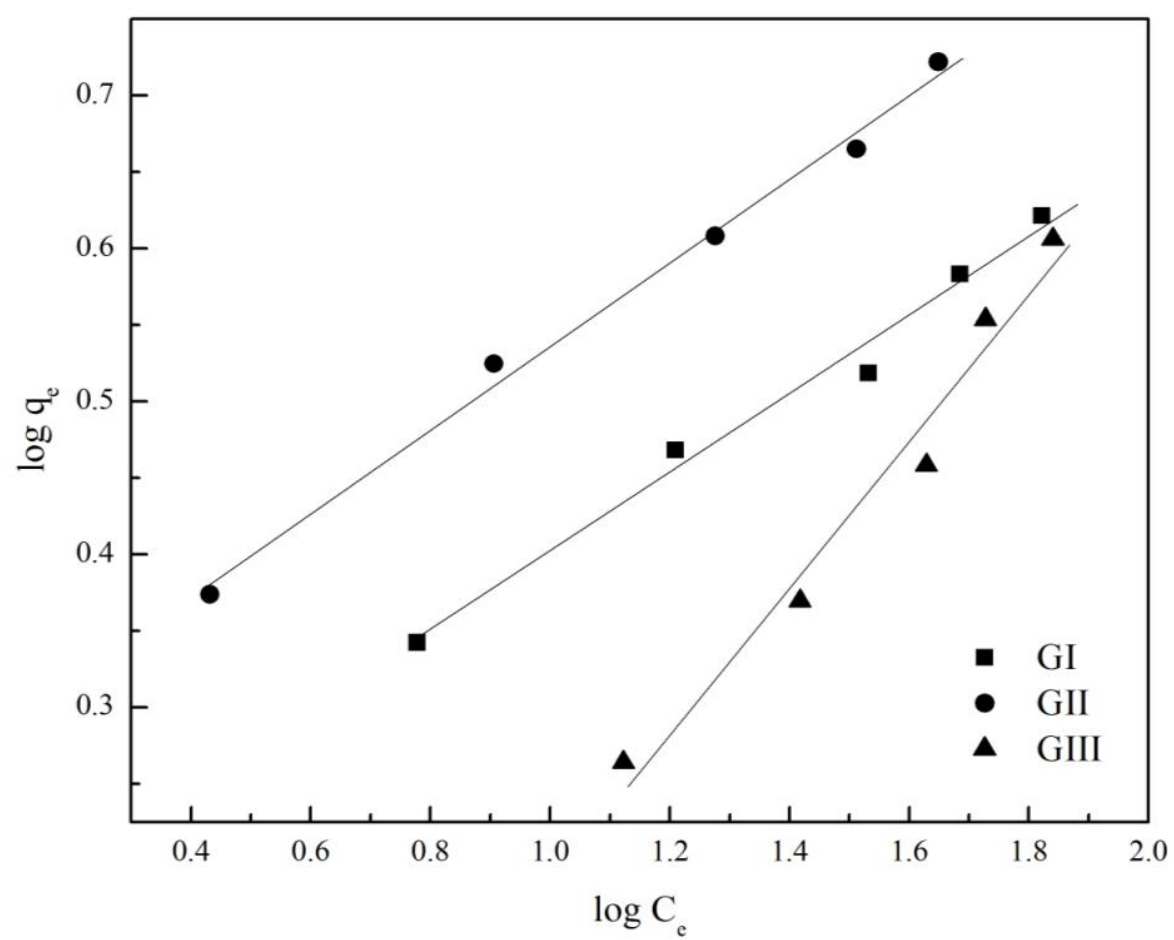

Figure 9. Freundlich adsorption isotherms for the adsorbents GI, GII and GIII

In Table 2 parameters of Langmuir and Freundlich adsorption isotherms were given for the investigated adsorbents.

Table 2. Parameters of Langmuir and Freundlich adsorption isotherms for the investigated adsorbents

\begin{tabular}{c|c|c|c|c|c|c}
\hline \multirow{2}{*}{ Adsorbents } & \multicolumn{3}{|c}{ Freundlich } & \multicolumn{3}{c}{ Langmuir } \\
\cline { 2 - 7 } & $\mathbf{K}_{\mathbf{f}}$ & $\mathbf{n}$ & $\mathbf{R}^{\mathbf{2}}$ & $\mathbf{K}_{\mathbf{L}}$ & $\mathbf{Q}_{\max }$ & $\mathbf{R}^{\mathbf{2}}$ \\
\hline GI & 1.3890 & 3.8585 & 0.98159 & 0.1099 & 4.6024 & 0.98232 \\
GII & 1.8256 & 3.6387 & 0.99181 & 0.1789 & 5.6860 & 0.98325 \\
GIII & 0.5108 & 2.0849 & 0.96289 & 0.0266 & 5.9687 & 0.87946 \\
\hline
\end{tabular}

Results obtained by this study are similar with results for clay modification with polymers (Stojiljkovic et al., 2014). This is not surprising because both NaCMC and polymers, which are used to modify clay, are long chain molecules that are expected to increase adsorption process. 


\section{Conclusions}

Suitability of the clay modified with $\mathrm{NaCMC}$ for the removal of toxic heavy metal (lead) from the aqueous solution was tested in adsorption studies. The effect of various factors, such as the effect of $\mathrm{pH}$ of the solution, temperature, quantity of the adsorbent, concentration of the adsorbate was determined in a series of the experiments. It was found that the adsorption, i.e. the percentage of removed lead increases with the increase of these parameters. Obtained Freundlich adsorption isotherms show extremely high correlation coefficient R, i.e. processes of equilibria on the investigated clays can be described using this equation. The series of conducted experiments shows that the clay modified with carboxymethyl cellulose is suitable for the removal of lead from waste waters. Removing metal ions from aqueous solutions by adsorption onto bentonite and its modifications is efficient and cheap technique. Further researches should be aimed to test adsorption properties of the clay modified with other long chain molecules, and to test its efficiency in removing heavy metal ions from water solutions in different conditions.

Acknowledgements. Vojkan M. Miljkovic and Stanisa Stojiljkovic want to thank for the financial support to Ministry of Education, Science and Technological Development of Republic of Serbia (grant number TR34012, OS172047). Authors are grateful to Dr Biljana Arsic for the help during the creation of the manuscript.

\section{REFERENCES}

[1] Adhikari, T., Singh, M. V. (2003): Sorption characteristics of lead and cadmium in some soils of India. - Geoderma 114: 81-92.

[2] Aklil, A., Mouflih, M., Sebti, S. (2004): Removal of heavy metal ions from water by using calcined phosphate as a new adsorbent. - J. Hazard. Mater. A112: 183-190.

[3] Arfaouia, S., Frini-Srasra, N., Srasra, E. (2008): Modelling of the adsorption of the chromium ion by modified clays. - Desalination 222: 474-481.

[4] Bhattacharyya, K. G., Gupta, S. S. (2007): Adsorptive accumulation of Cd(II), Co(II), Cu (II), $\mathrm{Pb}$ (II) and $\mathrm{Ni}$ (II) from water on montmorillonite: Influence of acid activation. - J. Colloid Interf. Sci. 310: 411-424.

[5] Celis, R., Hermosin, M. C., Cornejo, J. (2000): Heavy metal adsorption by functionalized clays. - Environ. Sci. Technol. 34: 4593-4599.

[6] Chaari, I., Fakhfakh, E., Chakroun, S., Bouzid, J., Boujelben, N., Feki, M., Rocha, F., Jamoussi, F. (2008): Lead removal from aqueous solution by Tunisian smectitic clay. - J. Hazard. Mater. 156: 545-551.

[7] Cooper, C., Jiang, J. Q., Ouki, S. (2002): Preliminary evaluation of polymeric Fe- and Almodified clays as adsorbents for heavy metal removal in water treatment. - J. Chem. Technol. Biotechnol. 77: 546-551.

[8] Guggenheim, S., Martin, R. T. (1995): Definition of clay and clay mineral: joint report of the AIPEA Nomenclature and CMS Committees. - Clay Clay Miner. 43(2): 255-256.

[9] Inglezakis, V. J., Stylianou, M. A., Gkantzoua, D., Loizidoua, M. D. (2007): Removal of $\mathrm{Pb}$ (II) from aqueous solution by using clinoptilolite and bentonite as adsorbents. Desalination 210(13): 248-256.

[10] Langmuir, I. J. (1918): The adsorption the gases on plane surfaces of glass, mica and platinum. - Am. Chem. Soc. 40 1361-1403.

[11] Lidsky, T. I., Schneider, J. S. (2003): Lead neurotoxicity in children: basic mechanisms and clinical correlations. - Brain 126: 5-19. 
[12] Mirić, M. O., Šorbajić, S. S. (2002): Zdravstvena ispravnost namirnica. Zavod za udžbenike i nastavna sredstva, Beograd.

[13] Momcilovic, M., Purenovic, M., Bojic, A., Zarubica, A., Randjelovic, M. (2011): Removal of lead(II)-ions from aqueous solutions by adsorption onto pine cone activated carbon. - Desalination 276: 53-59.

[14] Panayotova, M., Velikov, B. (2002): Kinetics of heavy metal ions removal by use of natural zeolite. - J. Environ. Sci. Health. A37: 139-148.

[15] Qiu, Y., Cheng, H., Xu, C., Sheng, G. D. (2008): Surface characteristics of crop residuederived black carbon and lead (II) adsorption. - Water Res. 42: 567-574.

[16] Resmi, G., Thampi, S. G., Chandrakaran, S. (2012): Removal of lead from wastewater by adsorption using acid-activated clay. - Environ. Technol. 37(5): 291-297.

[17] Scott, J., Guang, D., Naeramitmarnsuk, K., Thabuot, M., Amal, R. (2002): Zeolite synthesis from coal fly ash for the removal of lead ions from aqueous solution. - J. Chem. Technol. Biotechnol. 77: 63-69.

[18] Sen, A., Heredia, N., Senut, M. C., Land, S., Hollocher, K., Lu, X., Dereski, M. O., Ruden, D. M. (2015): Multigenerational epigenetic inheritance in humans: DNA methylation changes associated with maternal exposure to lead can be transmitted to the grandchildren. - Sci. Rep. 5: 14466.

[19] Stojiljkovic, S., Miljkovic, V., Nikolic, G., Kostic, D., Arsic, B., Barber, J., Savic, I., Savic, I. (2014): The influence of the addition of polymers on the physic-chemical properties of bentonite suspensions. - Sci. Sinter. 46(1): 65-73.

[20] Tokimoto, T., Kawasaki, N., Nakamura, T., Akutagawa, J., Tanada, T. (2004): Removal of lead ions in drinking water by coffee grounds as vegetable biomass. - J. Colloid Interface Sci. 281: 56-61.

[21] World Health Organisation (WHO). (2011): Guidelines for drinking-water quality - 4th ed., 383. http://whqlibdoc.who.int/publications/2011/9789241548151_eng.pdf.

[22] Yasemin, B., Zeki, T. (2007): Removal of heavy metals from aqueous solution by sawdust adsorption. - J. Environ. Sci. 19: 160-166.

[23] Yi, Y., Yang, Z., Zhang, S. (2011): Ecological risk assessment of heavy metals in sediment and human health risk assessment of heavy metals in fishes in the middle and lower reaches of the Yangtze River basin. - Environ. Pollut. 159: 2575-2585.

[24] Zhu, S., Hou, H., Xue, Y. (2008): Retraction notice to "Kinetic and isothermal studies of lead ion adsorption onto bentonite". - Appl. Clay Sci. 40: 171-178. 